\title{
Disentangling the Diversity of Forest Care Initiatives: A Novel Research Framework Applied to the Italian Context
}

\author{
Ilaria Doimo*(D), Mauro Masiero (iD) and Paola Gatto $(\mathbb{D}$ \\ Department of Land, Environment, Agriculture and Forestry, Università degli Studi di Padova, \\ 35020 Legnaro, Italy; mauro.masiero@unipd.it (M.M.); paola.gatto@unipd.it (P.G.) \\ * Correspondence: ilariadoimo@gmail.com
}

\begin{abstract}
In the effort to advance the knowledge of and disentangle the diversity of emerging forestbased initiatives for wellbeing, we propose (1) an umbrella definition (i.e., forest care initiatives (FCIs)), (2) a custom-made repository to collect and systematize information on FCIs in Italy, and (3) discuss a categorization scheme to cluster initiatives into three main categories according to target users, substitutability of the forest ecosystem, and the specificity of the health contributions to which they are aimed. We analyzed 232 initiatives, showing a lively panorama of Italian FCIs, mainly provided by private entities and civil society. FCI developments appear to be occasions for, but are not restricted to, rural and marginal areas delivering inclusive wellbeing services to a wide target user group and business opportunities. However, due to the novelty of this area of investigation, further research is needed to account for benefits and opportunities and to increase knowledge on enabling forest environments.
\end{abstract}

Keywords: forest care initiatives; forests; sustainable rural development; wellbeing; social health

Citation: Doimo, I.; Masiero, M.; Gatto, P. Disentangling the Diversity of Forest Care Initiatives: A Novel Research Framework Applied to the Italian Context. Sustainability 2021, 13, 492. https://doi.org/10.3390/ su13020492

Received: 7 December 2020 Accepted: 27 December 2020 Published: 6 January 2021

Publisher's Note: MDPI stays neutral with regard to jurisdictional clai$\mathrm{ms}$ in published maps and institutional affiliations.

Copyright: (C) 2021 by the authors. Licensee MDPI, Basel, Switzerland. This article is an open access article distributed under the terms and conditions of the Creative Commons Attribution (CC BY) license (https:// creativecommons.org/licenses/by/ $4.0 /)$.

\section{Introduction}

As stated in the EU Biodiversity Strategy for 2030, "Nature is as important for our mental and physical wellbeing as it is for our society's ability to cope with global change, health threats and disasters. We need nature in our lives" [1]. Large, continuous natural spaces like forests and more accessible woodlands in our cities provide increased air quality, health protection, and resilience to climate changes, as well as occasions for sociobehavioral and cultural ecosystem services (CESs) and even health outcomes [2-6]. Indeed, indirect (through sensory stimulation [7-12]) and direct contact with forest ecosystems can positively impact mental [13-19], physiological [20-22], and social wellbeing [23-27]. This could mitigate the consequences of urbanization processes such as the growth of non-communicable diseases [28], the increased pressure on social, educational and health services, the disconnection with nature, and the response to the need to have space for social interaction and stress relief [29-31]. This is matched with a generalized trend toward wellness and reconnection with the natural world [32,33]. In parallel, the rural and forestry worlds are facing structural changes toward a more service-centric economy [34]. Therefore, the expansion of forest-based ecosystem services and multiple uses is evolving in harmony with the emerging social demands for wellbeing. In fact, examples of organized initiatives enabling contact with forest ecosystems for wellbeing promotion are thriving [35]. From Japan's shinrin-yoku (i.e., forest bathing) and healing forests in the Republic of Korea, these initiatives are expanding throughout Europe and adapting next to other, better-established ones, such as forest kindergartens, outdoor museums, and social forestry practices $[5,16,36]$.

In the last few decades, European rural development policies have been gradually expanded toward improving the quality of life of rural populations and encouraging diversification of the rural economy, as well as multifunctionality [33]. The health and social sectors appear to increasingly look for alternatives to traditional treatments, therapy, and rehabilitation that also involve nature [37]. In this context, Green Care developed 
differently between countries, creating links between sectors not formerly linked [38,39]. In the same vein, forest care initiatives (FCIs) are now spreading and adapting to different socioeconomic contexts, resulting in a great diversity of activities for targeted people, the professionals involved, organization models, objectives, and uses of environmental resources. Initiatives include, for example, social inclusion of marginalized groups of people, activities supporting education and pro-environmental behaviors [27,40-42] (e.g., forest schools and forest pedagogy [43]), enhancing artistic and cultural inspiration [44] (e.g., through land art and contemporary art museums in forests), spiritual forests and forest burial initiatives [45], which are growing in countries like Austria and Germany (https:/ / www.ruheforst-deutschland.de/), initiatives enhancing the quality of social relationships, and encouraging reconnection with nature and increases in self-esteem. These FCIs have just been recently addressed by scholars [46-48], and research efforts are (1) focused on a limited range of initiatives, namely forest therapy and forest bathing, (2) mainly distinguishing initiatives according to the typologies of the health effects they provide [49], and moreover, (3) not setting clear terminology and definitions, often creating confusion about objectives and services provided by these initiatives. This hinders the possibility to account for wider wellbeing benefits, multipurpose initiatives, and a wealth of other differences between them.

Forest care initiatives are aimed at increasing people's wellbeing, not only focusing on diseases but also on people's needs, individuals' expectations, and their health and role within the community. Nevertheless, these initiatives contribute to wellbeing with different objectives, such as (1) therapeutic and rehabilitation effects for people with specific needs and health conditions [50-53], (2) preventive effects [5,54-59] and health-promoting effects [60-64], and (3) wellbeing effects, such as education, recreation, social inclusion, tourism, recreation, and spiritual, artistic, cultural inspiration, thus generating indirect health benefits in synergy with other sectors $[26,29,60,61,65,66]$. Such initiatives welcome the concept of people-centric care by the World Health Organization, enlarging it to nonclinical interventions and to the broad concept of wellbeing. Secondly, of course, all of the initiatives use the forest environment for its psychophysical regenerative potential and natural consequences as cognitive behavioral therapy $[29,67,68]$. However, various forest environments are used, from close-to-nature forests for wilderness and adventure therapy to peri-urban and urban forests $[1,69]$, to promote active lifestyles (for examples, see [60,62]) in hospitals for clinical therapy or rehabilitation interventions $[15,70]$. As a third point, some initiatives are highly dependent on certain forest areas to deliver their services while others are not, and different forests can interchangeably be used as a set to deliver certain services and benefits, from conducting ad hoc studies for forest therapy base certification in Japan [71] to the selection and inventory of specific areas and trails for social prescribing $[72,73]$ to wilderness and adventure therapy, which can be itinerant or also done in non-forest ecosystems. It is not rare to find multipurpose and holistic initiatives capturing and delivering more than one effect at time. Healing forests in the Republic of Korea (Information on Korean forest healing centers available at https: / / english.visitmedicalkorea. com/eng/wellnessKorea/wellnessKorea_03/wellnessKorea_03_3.jsp), for example, are places devoted to tourism, holistic wellness, and specific treatments. Different objectives entail different target users, from the wide general public to specific segments of the population or people with special needs (e.g., physical and mental disabilities, illnesses, and psychological disorders). The professionals involved, activities proposed, environmental features and partnerships would be tuned accordingly. This diversity requires an instrument to collect and standardize information and to further disentangle the differences between FCIs and understand their target users, contributions to wellbeing, and the role of the environment. The lack of univocal and clear definitions results in gaps with regard to both an umbrella term embracing them and shared ways to categorize and classify single initiatives under the umbrella. This reflects the information gaps and lack of attention within policies and gray literature including, for instance, national forest reporting initiatives. 


\subsection{Objectives}

We argue that FCIs provide a wide range of sociobehavioral and CES benefits, are often multipurpose, serve a wide target of people, and use the forest environment in different ways. The problem faced is a generalized lack of information on the initiatives, as well as tools to collect and standardize the information about their relevant environmental, social, and economic aspects. Although the research on health effects is growing, there is a lack of discussion about these aspects. This study aims to disentangle the multifaceted concept of forest initiatives for wellbeing and gain better knowledge and understanding of ongoing initiatives in order to grasp and analyze useful information that might support their development.

The general objective will be achieved through the following specific objectives:

(1) To develop a comprehensive definition for forest care initiatives;

(2) To collect and systematize information through the development of an inventory of forest care initiatives in Italy;

(3) To propose a scheme to catch the diversity and characterize the wealth of existing initiatives.

\subsection{Scope and Definition}

Existing literature shows how being in contact with a forest produces positive health effects. These benefits can be delivered just by making forests and woodlands accessible to people. However, purposely managed natural areas and activities can increase effectiveness, engage wider target groups, and provide development opportunities for the forest sector $[36,74]$.

In the effort to identify the boundaries defining the scope of our research, and to be able to consider the wider contributions for people and communities, we look for initiatives that (1) are carried out in forest or woodland areas, or in a mixed ecosystem with the presence of a forest area, (2) have a manifested intention of increasing the level of wellbeing of people (i.e., the activity is organized, the aim is clearly stated and evidence or effort for improving health, social wellbeing, is provided), and (3) are organized with a provider or promoter, thus excluding spontaneous, self-leading activities in natural areas not devoted to these purposes. The initiatives must be presented by a provider offering the space or infrastructure and providing a guide or assistant.

Given these premises, we define FCIs as organized initiatives, encompassing everything from single stand-alone activities to national programs, which can be both for profit and not-for-profit, and that use (passively or actively) contact with a forest's elements and atmosphere to increase the level of wellbeing of individuals, people, and communities. The term care is borrowed from the Green Care literature, and thus here is intended not just as the act of caring, but encompasses interventions that lead to maintaining, promoting, and providing health and social rehabilitation [48]. In this sense, we intend the term care in its broadest sense, integrated with the definition of wellbeing provided by the World Health Organization. Therefore, FCIs comprise aspects of healthcare, social inclusion and rehabilitation, health prevention with clinical assistance to broaden wellness and relaxation, education ranging from pedagogy to opportunities for disaffected people, spiritual and inspirational values, employment, and livelihood.

\section{Materials and Methods}

Building on the above-reported definition of FCIs, we identified FCIs in Italy through desktop research on Google, combining three sets of keywords representative of (a) the environment (e.g., foresta, bosco, natura, and outdoor), (b) FCIs (e.g., forest bathing, bagno di foresta, asilo in bosco, and benessere) and (c) territorial units (Nomenclature of Territorial Units for statistics 2). This search was enriched with additional data mining via scientific and gray literature, personal contacts, and snowball sampling. The research was conducted from January 2019 to July 2020. We included those FCIs that presented clear objectives of wellbeing. Thus, simple or traditional tourism, sport, and recreational initiatives in forest areas were excluded (e.g., adventure parks in the forest were excluded because they 
are generally well-established, but only included when they integrate services oriented to wellbeing or environmental education). The units of the survey were the single FCIs. There are no official databases of FCIs, so it was not possible to report precise numbers and data. In addition, existing FCIs do not share precise standards and requirements; thus, it was necessary to perform a one-by-one screening of the initiatives. Given the unprecedented situation due to the spread of COVID-19, with the adoption of social distancing measures, many initiatives were forced to close during the last period of our research. Hence, such initiatives were considered active if it was clearly stated that they were suspended due to above-mentioned reasons.

A repository was developed in order to collect and systematize information from as many cases as possible, with a quick procedure and relatively low level of information at our disposal, and organize them into a database. The structure and initial set of indicators was broadly inspired by the one developed by [75] for payments for ecosystem services. In the effort of standardized yet fair illustration of a new field, we used an inductive process based on literature review and experts' elicitation. A constant feedback loop enabled us to refine the set of dimensions so as to capture information that could be standardized and was available crosswise to the diverse initiatives. Table S1 reports the full list of dimensions and indicators used. The selected dimensions spanned five broad domains:

- General description and location. Regions were identified according to Eurostat NUTS 2 classification, and codes of territorial units retrieved from the Italian National Institute of Statistics (Istituto Nazionale di Statistica (ISTAT)) were used for the geographic references of the initiatives (https://www.istat.it/it/archivio/6789). For the identification of the rural areas, we referred to the national classification adopted by the National Strategy Plan (NSP) for Rural Development at the NUTS 3 level ( https:/ / www.reterurale.it/areerurali), which distinguishes among zones A (i.e., urban areas), B (i.e., rural areas with intensive agriculture), C (i.e., intermediate rural areas) and D (i.e., rural areas with overall development problems):

- Contributions to public health, and activities and services supported. Contributions to public health were distinguished into physiological, psychological, and social, as presented in [6], assessed subjectively by interpreting the manifested aims and objectives of the FCIs or by eliciting the FCIs' managers when not clear otherwise. Activities and practices supported by the ecosystem through the initiative were inspired by Fish et al. [76], with the definition of CES and its framework developed by Scottish Natural Heritage [77] and then refined based on the FCIs' peculiarities;

- $\quad$ Target users and experience in the forest. Targets were categorized as (1) the general public, (2) specific, when referring to a homogeneous cluster of a population (e.g., children, the elderly, and immigrants), and (3) people with special needs (e.g., disabled or ill people). Experiences were distinguished into (1) self-leading without the need of a guide, (2) assisted, with the presence of a guide or practitioner, and (3) experiences effective both with and without a guide;

- Hosting natural area. Hosting natural areas were divided into forests, other wooded land as defined by the Food and Agriculture Organization [78], planted forests, parks intended as public spaces designated for recreational purposes with the presence of trees, and mixed ecosystems (e.g., forests, grasslands, and shrublands), together with not better specified areas. Data for all identified FCIs had been georeferenced, and a QGIS point vector (shapefile) was developed. By overlapping this with the 2018 Corine Land Cover data retrieved from the Copernicus database (www.copermnicus.eu), it was possible to associate FCIs to the corresponding (broad) forest categories (i.e., broadleaf, coniferous, or mixed forests);

- Managing organization. We categorized the typologies of management organizations (i.e., as private (nonprofit or for business), public, or public-private), the main typology of the actors involved in the management of the FCI, and the temporal scale of the initiative, whether permanent, on a seasonal basis, or an event or project with a definite lifespan. 
To analyze the initiatives gathered in our sample, we employed a qualitative, interpretivist approach, which is appropriate for dealing with textual data $[79,80]$. We used a subjective interpretation of the information gathered through the desktop research, organizing the textual information of each initiative indexed into the repository. Data gathered and organized through the repository enabled a quantitative analysis to delineate a picture of this emerging sector in Italy.

Through an inductive approach based on observation, it was possible to further aggregate the FCIs in our sample based on their core activities and services supported. This allowed us to group the FCIs into typologies with a certain degree of coherence of activities performed, objectives of public health, and target users. At this stage, managing organization was not considered as a key parameter for FCI classification and therefore was not explicitly referred to. With this interpretation, we again performed quantitative analysis with pivot tables, observing the remaining four domains of information reported above (i.e., general description and location, contributions to public health, target users, and hosting natural areas), according to the different typologies of the FCIs identified. The discussion of results, also based on direct observation, field visits, and consultation with practitioners and experts, allowed for the generalization of a categorization scheme for FCIs that took into account the relationship with the hosting environment, the specificity of the public health objectives, and the target users addressed.

\section{Setting the Scene of the Case Study}

Forest cover has continuously expanded in Italy during the last decade $(+4.9 \%)$, reaching 9,165,505 hectares of forests and 1,816,508 hectares of other wooded land [81]. Today, this represents $36.4 \%$ of the total land area, ranking Italy sixth in Europe in terms of relative forest cover [81]. Private forest ownership, mainly consisting of individual owners, accounts for $66.2 \%$ of the total forest area, with the remaining $33.8 \%$ being public (mainly municipal or regional) [82]. Although forests are expanding, harvest rates are far below the European average, and $60 \%$ of the yield consists of firewood. This means that Italian forests have low anthropogenic pressures, but on the other side, there is a strong dependence on imported wood. Private owners show low interest in managing forests, and indeed, forest expansion is mainly due to the abandonment of pastures and rural areas rather than resulting from afforestation or reforestation activities. Indeed, the main goal of Italian forest policies is soil and water protection, since the very irregular morphological features. Furthermore, 160,000 ha are old-growth forests, which are hotspots for forest biodiversity. According to Legislative Decree $42 / 2004,100 \%$ of the forest area is subject to landscape restrictions, and $35 \%$ is under environmental protection. Italian forests are among the most biodiverse in Europe, hosting 117 different tree species, accounting for two-thirds of all European tree species. Italian forests are traditionally multifunctional and used for tourism and recreation. Recently, increasing societal engagement in forest wellness and a growing number of forest-based wellbeing, artistic, and cultural initiatives have emerged [81]. Most of these initiatives have just recently been started and represent a novelty for the Italian forestry sector. While there is vivacity at the ground level, the public sector and policy initiatives often lag behind. This ultimately results in a gap in the legislative and policy framework that should stay at the background of emerging initiatives, which results in fragmentation and poor integration or coordination. The few existing regulations for FCIs are developed at the regional level, mainly for educational initiatives supporting livelihood diversification and endorsed by regional authorities for agriculture and forestry. With these few exceptions, there are no official recognitions, regulations, quality standards, or inventories available for FCIs in Italy. Considering the challenges in public health and the main trend in the forestry sector, we believe Italy can provide interpretations and insights that can also be useful for other countries. 


\section{Results}

\subsection{General Description of FCIs Characteristics}

We identified 232 FCIs in Italy (please refer to Supplementary Materials for the complete repository), and a summary of the results is presented in Table 1.

Table 1. Summary of the Results.

\begin{tabular}{|c|c|c|c|c|}
\hline \multirow{20}{*}{$\begin{array}{l}\text { General Description } \\
\text { and Location }\end{array}$} & Dimension & Indicators & $n$ & $\%$ \\
\hline & \multirow{5}{*}{ Status } & Active & 181 & 78.02 \\
\hline & & Pilot & 1 & 0.43 \\
\hline & & Design Phase & 5 & 2.16 \\
\hline & & Abandoned & 16 & 6.9 \\
\hline & & Unknown & 29 & 12.5 \\
\hline & \multirow{4}{*}{ Scale of action } & Local & 190 & 81.9 \\
\hline & & Regional & 35 & 15.09 \\
\hline & & National & 6 & 2.59 \\
\hline & & International & 1 & 0.43 \\
\hline & \multirow{5}{*}{ PSN rural class } & $\mathrm{A}$ & 67 & 28.87 \\
\hline & & $\mathrm{B}$ & 38 & 16.37 \\
\hline & & $\mathrm{C}$ & 40 & 17.24 \\
\hline & & $\mathrm{D}$ & 78 & 33.62 \\
\hline & & NA (Not Applicable) & 9 & 3.87 \\
\hline & \multirow{5}{*}{ Type of Initiative } & Permanent & 130 & 56.03 \\
\hline & & Seasonal & 46 & 19.83 \\
\hline & & Event or Project & 43 & 18.53 \\
\hline & & Network or Research & 9 & 3.88 \\
\hline & & NA & 4 & 1.72 \\
\hline \multirow{15}{*}{$\begin{array}{l}\text { Contribution to Health } \\
\text { and Activities and } \\
\text { Services Supported }\end{array}$} & \multirow{3}{*}{ Contributions to health ${ }^{* *}$} & Physiological & 68 & 29.31 \\
\hline & & Psychological & 86 & 37.07 \\
\hline & & Social & 183 & 78.88 \\
\hline & \multirow{12}{*}{$\begin{array}{l}\text { Activities and services } \\
\text { supported by FCIs }\end{array}$} & Sport & 42 & 18.1 \\
\hline & & Recreation and Tourism & 96 & 41.38 \\
\hline & & Adventure and Wilderness & 106 & 45.69 \\
\hline & & $\begin{array}{l}\text { Psychophysical Therapy or } \\
\text { Rehabilitation }\end{array}$ & 29 & 12.5 \\
\hline & & Wellness and Relaxation & 74 & 31.9 \\
\hline & & Spirituality & 24 & 10.34 \\
\hline & & Social Cohesion & 47 & 20.26 \\
\hline & & Social Inclusion (Social Care) & 28 & 12.07 \\
\hline & & Inspiration (Artistic or Cultural) & 63 & 27.16 \\
\hline & & Learn from Nature & 118 & 50.86 \\
\hline & & $\begin{array}{l}\text { Livelihood Provision and Income } \\
\text { diversification }\end{array}$ & 13 & 5.6 \\
\hline & & FCIs with Multiple Contributions & 219 & 93 \\
\hline \multirow{8}{*}{$\begin{array}{l}\text { Target Users and } \\
\text { Experience in the Forest }\end{array}$} & \multirow{4}{*}{ Target Users } & General Public & 98 & 42.24 \\
\hline & & Specific Target & 107 & 46.12 \\
\hline & & Special Needs & 25 & 10.78 \\
\hline & & Mixed or Not Specified & 2 & 0.86 \\
\hline & \multirow{4}{*}{ User's experience } & Self-Leading & 40 & 17.24 \\
\hline & & Assisted & 159 & 68.53 \\
\hline & & Both & 28 & 12.07 \\
\hline & & NA & 5 & 2.16 \\
\hline
\end{tabular}


Table 1. Cont.

\begin{tabular}{|c|c|c|c|c|}
\hline \multirow{3}{*}{ Hosting Natural Area } & Hosting Area & $\begin{array}{c}\text { Fixed (One) } \\
\text { Fixed (More Than One) } \\
\text { Itinerant } \\
\text { NA }\end{array}$ & $\begin{array}{l}124 \\
12 \\
65 \\
31\end{array}$ & $\begin{array}{c}53.45 \\
5.17 \\
28.02 \\
13.36\end{array}$ \\
\hline & Ecosystem & $\begin{array}{c}\text { Forest or Woodland } \\
\text { Park } \\
\text { Planted } \\
\text { Mixed or Unspecified }\end{array}$ & $\begin{array}{c}96 \\
19 \\
10 \\
107\end{array}$ & $\begin{array}{c}41.38 \\
8.19 \\
4.31 \\
46.12\end{array}$ \\
\hline & Forest Type * & $\begin{array}{l}\text { Bradleaved } \\
\text { Coniferus } \\
\text { Mixed } \\
\text { NA }\end{array}$ & $\begin{array}{c}65 \\
21 \\
23 \\
118\end{array}$ & $\begin{array}{c}28.63 \\
9.25 \\
10.13 \\
51.98\end{array}$ \\
\hline \multirow{2}{*}{$\begin{array}{c}\text { Managing } \\
\text { Orgnanization }\end{array}$} & Type of Organization & $\begin{array}{c}\text { Private Nonprofit } \\
\text { Private for Businesses } \\
\text { Public } \\
\text { Public-Private } \\
\text { NA }\end{array}$ & $\begin{array}{c}127 \\
74 \\
14 \\
15 \\
2\end{array}$ & $\begin{array}{r}54.74 \\
31.89 \\
6.03 \\
6.46 \\
0.86\end{array}$ \\
\hline & Actors & $\begin{array}{l}\text { Civil Society or Individuals } \\
\text { Governance or Public Bodies } \\
\text { Academic or Technical Bodies } \\
\text { Mixed } \\
\text { NA }\end{array}$ & $\begin{array}{c}179 \\
9 \\
2 \\
41 \\
1\end{array}$ & $\begin{array}{c}77.15 \\
3.87 \\
0.86 \\
17.67 \\
0.43\end{array}$ \\
\hline \multicolumn{2}{|c|}{ Source of Information } & $\begin{array}{l}\text { Scientific Literature } \\
\text { Gray Literature } \\
\text { Website } \\
\text { Personal Contact }\end{array}$ & $\begin{array}{c}0 \\
8 \\
196 \\
28\end{array}$ & $\begin{array}{c}0 \\
3.45 \\
84.48 \\
12.07\end{array}$ \\
\hline
\end{tabular}

* Percentages were calculated from a total of $n .=229$ entries, as it was not possible to identify an exact location for three forest care initiatives (FCIs). ${ }^{* *}$ Percentages were calculated from a total of $n .=232$ entries; however, each FCI could include multiple contributions and services.

In $22 \%(n .=52)$ of the cases, it was not possible to date back to the exact year of launch due to a scarcity of information (Figure 1). However, FCIs have been continuously growing since 2012, peaking in 2017 with 27 new initiatives.

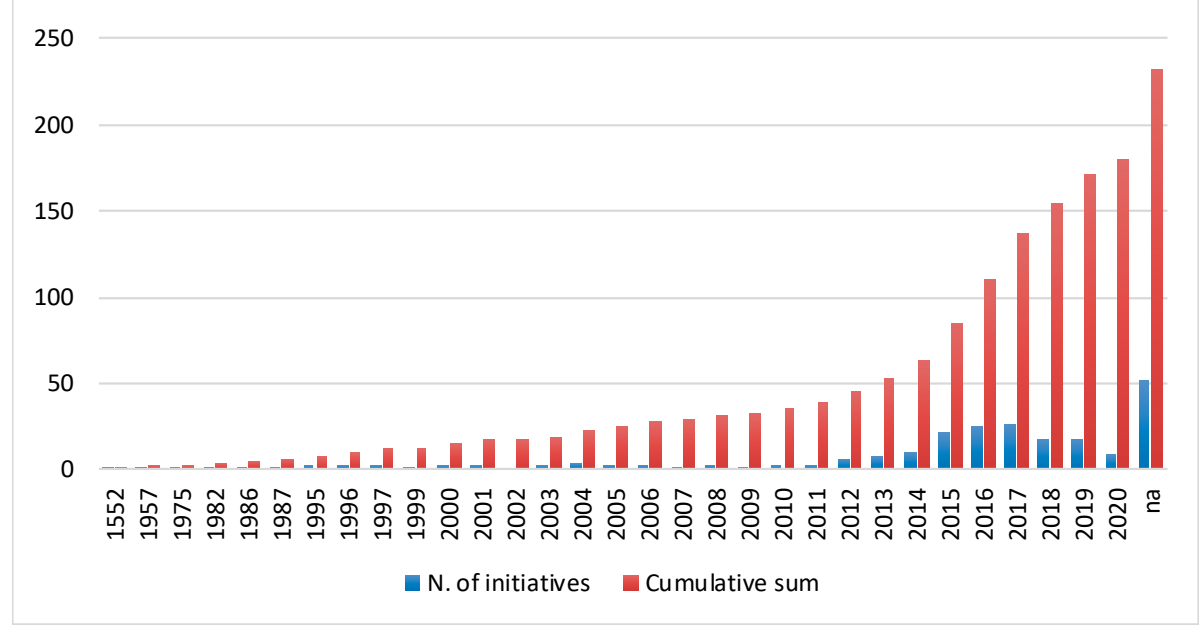

Figure 1. Number of initiatives grouped by year of establishment and the cumulative sum.

The FCIs analyzed are predominantly active at the local level, meaning that the supply of the wellbeing services is linked to a specific territory, but the users might hail from the entire national territory. There is an average of $n .=12.6$ FCIs per region, with a maximum 
of $n .=47$ FCIs in Trentino-Alto Adige/Südtirol (northeast) and no FCIs found in Molise (southeast) or Calabria (southwest) (Figure 2a).

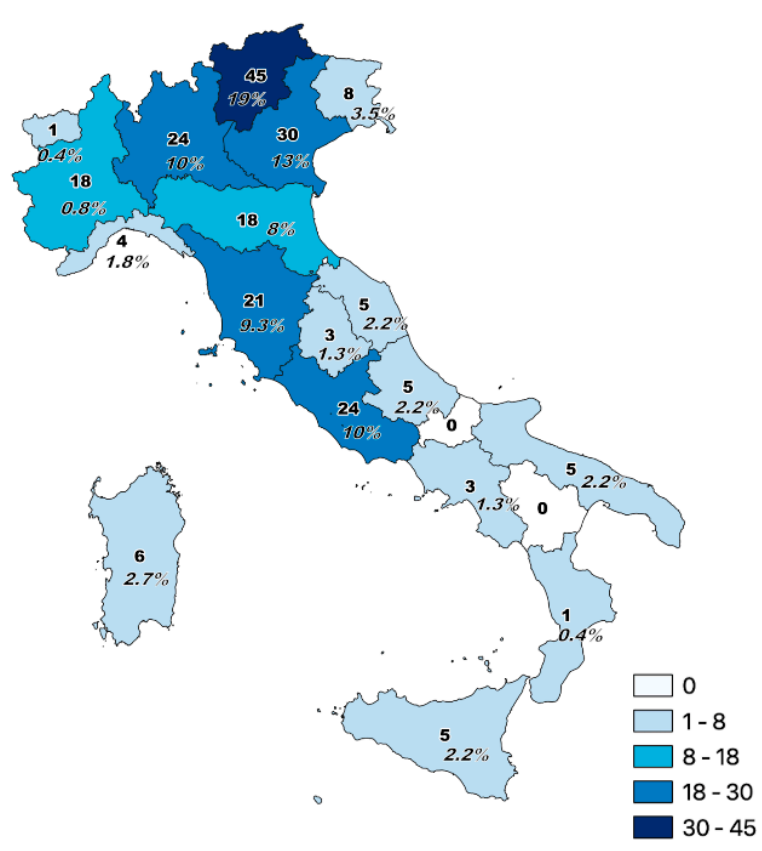

(a)

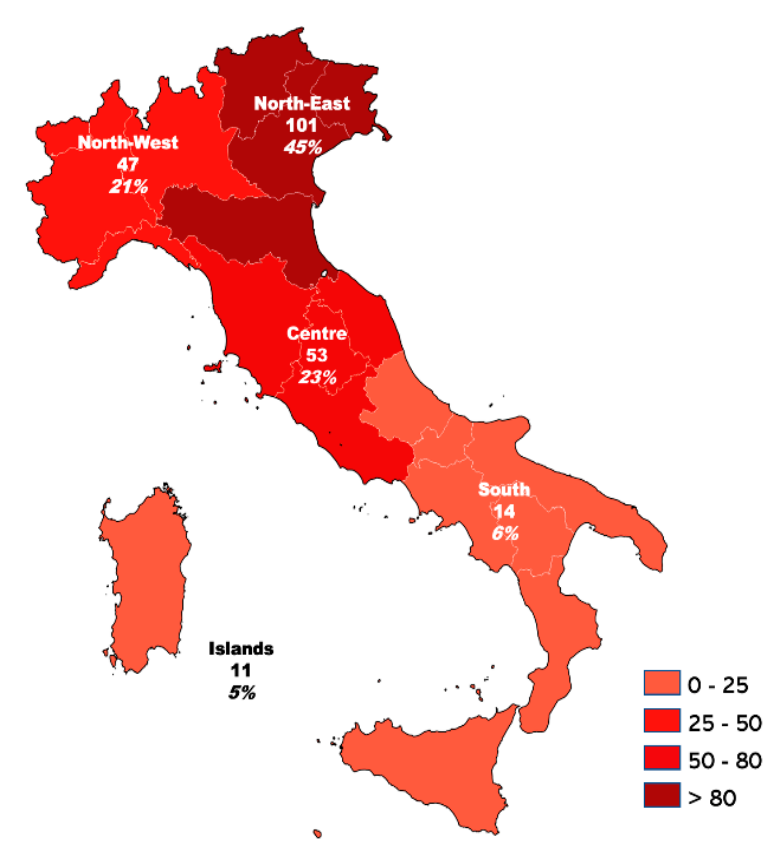

(b)

Figure 2. Number and percentage of FCIs divided by (a) NUTS2 regions and (b) macro areas, as identified by Istituto Nazionale di Statistica (ISTAT) classification.

About $66 \%$ of the FCIs were located in the north of the country (Figure $2 b$ ), in particular in the northeastern regions (e.g., Trentino-Alto Adige/Südtirol, Veneto, Friuli-Venezia Giulia, and Emilia-Romagna). About $34 \%$ of the FCIs were in rural areas with overall development problems (class D). The share of FCIs in rural areas increased to $67 \%$ when initiatives located in class B (intensive agriculture rural areas) and C (intermediate rural areas) areas were considered.

About $37 \%$ of the initiatives presented multiple contributions to health. The majority of the FCIs $(79 \%)$ were motivated by the generation of social benefits for people's wellbeing. Almost all (94\%) of the FCIs presented multiple (i.e., at least two) activities and interactions for supporting wellbeing, with a prevalence of learn from nature, wilderness and adventure $(46 \%)$, tourism and recreation $(41 \%)$, and wellness and relaxation $(32 \%)$ initiatives.

There was a fair division between FCIs designed for a specific group of people and those intended for the general public. In $68 \%$ of the cases, the users were assisted and guided during their experience in the forest, while self-leading experiences were less common.

The general tendency was to utilize one single and fixed natural area (53\%) for the activities, with the initiatives at regional scales keener on being itinerant within the regional territory. The very few initiatives active at the national and international levels were prevalently FCIs proposing training and courses.

Despite the inherent bond with woodlands FCIs are supposed to have, the information about the hosting natural space was marginally present in FCIs' communication and publicly available information. Indeed, in $46 \%$ of the cases, specific information on the type of ecosystem used for hosting activities was not available, or the activities were carried out in more than one ecosystem (often a combination of forest and non-forest mountain ecosystems). Where information on the hosting environment was disclosed, forest or woodland areas were the predominant hosting environments for the FCIs, with broadleaf forests being reported by $29 \%$ of the initiatives. Unfortunately, most of the FCIs (52\%) did 
not report data on the forest type, or it was not possible to clearly link initiatives to one or more specific forest types.

Private organizations managed $87 \%$ of the FCIs, of which $55 \%$ were nonprofit and $32 \%$ were for business. Civil society and individuals were the main typology of stakeholders involved in providing wellbeing benefits from forests (77\%). In 55\% of the cases, FCIs were managed by private nonprofit subjects (e.g., civil society organizations or individuals) offering year-round services, which did not necessarily imply that they were active every day, but they had structured programs adapting to the seasons' conditions.

\section{Discussion}

FCIs can be viewed as an umbrella term summarizing a wide range of activities, based on which it was possible to scout and analyze 232 initiatives complying with the definition.

The analysis revealed that FCIs in Italy are mainly private initiatives, specifically nonprofit ones, involving civil society and individuals. This gives rise to two considerations. On the one side, it confirms the vivacity of this emerging sector and the increasing role of civil society in providing inclusive services for individuals and communities. On the other, it can be seen as a signal of low support from public administrations toward forestryrelated sectors $[83,84]$. The results confirmed the assumptions that FCIs provide multiple benefits for wellbeing, and also that single initiatives are engaged in delivering multiple services. Furthermore, FCIs seem to be a valid opportunity for rural areas, namely for expanding the provision of inclusive services for health and wellbeing in marginal areas characterized by a lack of services and showing high depopulation rates. This, enhanced by collaboration opportunities with other sectors (e.g., health, education, and social care), makes FCIs a strategic opportunity to support "future green forest jobs" [85]. In order to better explore this opportunity, it would be necessary to assess links between sustainable forest management and FCIs.

FCIs are concentrated in Northern Italy, where productive high forests are also located. This might reveal a preference for high forests for FCIs-which should be better investigated-and also that the provision of sociobehavioral and CES benefits can, in principle, coexist with traditional forest activities. FCIs are largely located in Alpine regions and are particularly devoted to wellness tourism and active holidays. On the one side, it is possible to argue that mountains and pristine landscapes are the preferred location for regenerative purposes. On the other, strong tourism governance might favor the development of such FCIs. The analysis, however, did not significantly fill the information gap about the preferred and more suitable hosting ecosystems for FCIs [59].

\subsection{FCIs Characterization into Typologies}

Using observation and induction, a case-based clustering of FCIs into typologies was done. The clustering was based on the core activity or services proposed, according to the available information collected through desktop research. Analysis performed after clustering highlighted that the various FCI typologies showed differences in terms of health and wellbeing objectives, the target users they addressed, and the substitutability of the environments hosting them. A summary of the reinterpretation of results, enabling different predominant patterns to emerge, is proposed in Table 2, where the seven typologies identified are described and the associated category is anticipated (for a full description, see Section 4.6). The results of Table 2 are discussed in Sections 4.2-4.5. 
Table 2. Summary of the main FCI typologies included in the study, their key features, and their categorization.

\begin{tabular}{|c|c|c|c|c|c|c|}
\hline Typology & $\begin{array}{l}\text { N (\%) of Cases } \\
\text { Identified } \\
\text { within the } \\
\text { Repository }\end{array}$ & Description & Category & $\begin{array}{l}\text { Contributions } \\
\text { to Health and } \\
\text { Activities } \\
\text { Supported }\end{array}$ & Target Users & $\begin{array}{l}\text { Environment } \\
\text { Substitutability }\end{array}$ \\
\hline $\begin{array}{l}\text { Forest- } \\
\text { based } \\
\text { Therapy } \\
\text { (FT) }\end{array}$ & $9(4 \%)$ & $\begin{array}{l}\text { FCIs focused on } \\
\text { treatment and } \\
\text { rehabilitation } \\
\text { practices, based on } \\
\text { contact with forest } \\
\text { ecosystems and } \\
\text { requiring direct } \\
\text { involvement and } \\
\text { collaboration of the } \\
\text { health sector. } \\
\text { Therapies are } \\
\text { transferred and } \\
\text { adapted to the } \\
\text { forest environment } \\
\text { with the } \\
\text { collaboration of } \\
\text { different areas of } \\
\text { expertise. }\end{array}$ & $\begin{array}{l}\text { Therapy and } \\
\text { rehabilitation }\end{array}$ & $\begin{array}{l}\text { Physiological, } \\
\text { psychological, } \\
\text { and social }\end{array}$ & $\begin{array}{l}\text { Special needs } \\
\text { Assisted }\end{array}$ & 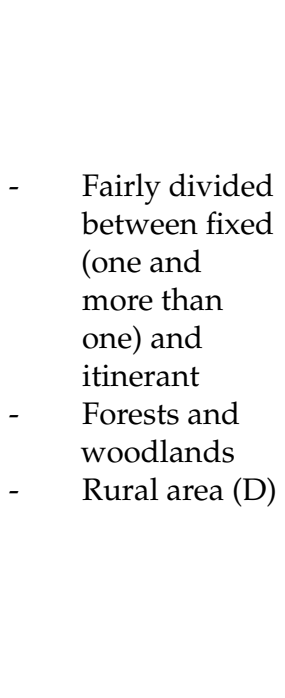 \\
\hline $\begin{array}{l}\text { Social } \\
\text { Inclusion } \\
\text { (SI) }\end{array}$ & $19(8 \%)$ & $\begin{array}{l}\text { FCIs aimed at } \\
\text { providing } \\
\text { marginalized } \\
\text { groups of people } \\
\text { with inclusive } \\
\text { opportunities for } \\
\text { improving social } \\
\text { and emotional } \\
\text { skills, or specific } \\
\text { working skills, } \\
\text { reducing } \\
\text { inequalities in the } \\
\text { access to nature } \\
\text { with the final } \\
\text { objective to } \\
\text { promote their social } \\
\text { integration. This is } \\
\text { normally achieved } \\
\text { via measures } \\
\text { delivered by } \\
\text { trained } \\
\text { professionals } \\
\text { (non-clinical } \\
\text { services). }\end{array}$ & $\begin{array}{l}\text { Prevention } \\
\text { and } \\
\text { Promotion }\end{array}$ & $\begin{array}{c}\text { Social (and } \\
\text { psychological) }\end{array}$ & $\begin{array}{l}\text { Special needs } \\
\text { Assisted }\end{array}$ & $\begin{array}{ll}\text { - } & \text { Itinerant } \\
\text { - } & \text { Mixed } \\
\text { ecosystem, } \\
\text { mainly } \\
\text { involving } \\
\text { mountains } \\
\text { Urban area } \\
\text { (A): this is } \\
\text { referred to the } \\
\text { headquarters, } \\
\text { and activities } \\
\text { are carried } \\
\text { out in } \\
\text { mountainous } \\
\text { areas }\end{array}$ \\
\hline
\end{tabular}


Table 2. Cont

\begin{tabular}{|c|c|c|c|c|c|c|}
\hline Typology & $\begin{array}{l}\text { N (\%) of Cases } \\
\text { Identified } \\
\text { within the } \\
\text { Repository }\end{array}$ & Description & Category & $\begin{array}{c}\text { Contributions } \\
\text { to Health and } \\
\text { Activities } \\
\text { Supported }\end{array}$ & Target Users & $\begin{array}{l}\text { Environment } \\
\text { Substitutability }\end{array}$ \\
\hline $\begin{array}{l}\text { Wellness } \\
\text { (WELL) }\end{array}$ & $64(28 \%)$ & $\begin{array}{l}\text { FCIs promoting } \\
\text { healthy lifestyles } \\
\text { through light } \\
\text { physical activities } \\
\text { and sensory } \\
\text { experiences in the } \\
\text { woodlands, such as } \\
\text { forest bathing, } \\
\text { mindfulness, } \\
\text { breathing exercises, } \\
\text { forest spas, yoga, } \\
\text { and other activities } \\
\text { for relaxation and } \\
\text { personal growth in } \\
\text { the forest. Such } \\
\text { initiatives } \\
\text { encourage a soulful } \\
\text { connection with } \\
\text { nature, prevent } \\
\text { stress and } \\
\text { technostress, and } \\
\text { support mental } \\
\text { restoration. }\end{array}$ & $\begin{array}{l}\text { Prevention } \\
\text { and } \\
\text { Promotion }\end{array}$ & $\begin{array}{l}\text { Psychological } \\
\text { (and } \\
\text { physiological) }\end{array}$ & $\begin{array}{l}\text { General } \\
\text { public } \\
\text { Assisted }\end{array}$ & 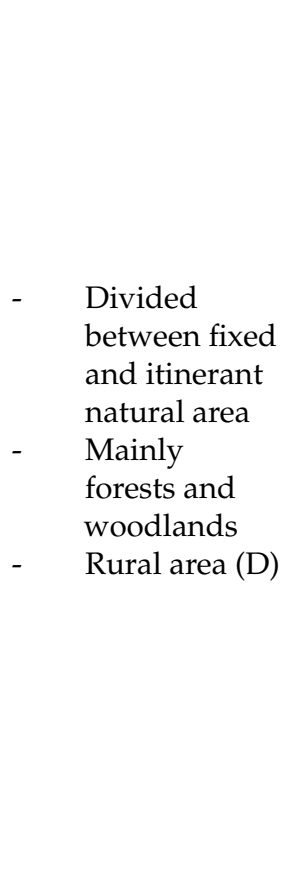 \\
\hline $\begin{array}{l}\text { Education } \\
\text { (EDU) }\end{array}$ & $89(38 \%)$ & $\begin{array}{l}\text { FCIs involving } \\
\text { experience- } \\
\text { oriented learning in } \\
\text { nature, } \\
\text { environmental } \\
\text { education, active } \\
\text { engagement with } \\
\text { natural elements to } \\
\text { develop gross and } \\
\text { fine motor abilities, } \\
\text { inspiration of } \\
\text { creativity and } \\
\text { imagination } \\
\text { through interaction } \\
\text { with natural } \\
\text { environments, and } \\
\text { stimulating } \\
\text { positive behaviors } \\
\text { toward nature. } \\
\text { FCIs falling within } \\
\text { this typology are } \\
\text { mainly, but not } \\
\text { only, addressed to } \\
\text { children and young } \\
\text { kids. }\end{array}$ & $\begin{array}{c}\text { Synergic } \\
\text { benefits }\end{array}$ & Social & $\begin{array}{l}\text { Specific target } \\
\text { Assisted }\end{array}$ & $\begin{array}{l}\text { Mainly one } \\
\text { fixed natural } \\
\text { area, with } \frac{1}{4} \\
\text { of the } \\
\text { initiatives not } \\
\text { having } \\
\text { enough } \\
\text { information } \\
\text { mixed or not } \\
\text { specified, } \\
\text { with mainly } \\
\text { no } \\
\text { information } \\
\text { on the } \\
\text { ecosystem } \\
\text { Urban area } \\
\text { (A) }\end{array}$ \\
\hline
\end{tabular}


Table 2. Cont

\begin{tabular}{|c|c|c|c|c|c|c|}
\hline Typology & $\begin{array}{c}\text { N (\%) of Cases } \\
\text { Identified } \\
\text { within the } \\
\text { Repository }\end{array}$ & Description & Category & $\begin{array}{c}\text { Contributions } \\
\text { to Health and } \\
\text { Activities } \\
\text { Supported }\end{array}$ & Target Users & $\begin{array}{c}\text { Environment } \\
\text { Substitutability }\end{array}$ \\
\hline $\begin{array}{l}\text { Artistic and } \\
\text { Cultural } \\
\text { Inspiration } \\
\text { (ART) }\end{array}$ & $38(16 \%)$ & $\begin{array}{l}\text { FCIs where forest } \\
\text { and woodland } \\
\text { areas are } \\
\text { transformed into } \\
\text { open-air museums, } \\
\text { populated by } \\
\text { site-specific art } \\
\text { pieces or by private } \\
\text { collections } \\
\text { displayed in the } \\
\text { natural } \\
\text { environment. } \\
\text { Woodlands used as } \\
\text { stages for concerts, } \\
\text { theatrical pieces, } \\
\text { and workshops are } \\
\text { also included. }\end{array}$ & $\begin{array}{l}\text { Synergic } \\
\text { benefits }\end{array}$ & Social & $\begin{array}{c}\text { General } \\
\text { public } \\
\text { Self-leading }\end{array}$ & $\begin{array}{ll}\text { - } & \text { One fixed } \\
\text { natural area } \\
\text { - } & \text { Mainly } \\
\text { forests and } \\
\text { - } \quad \text { Roodlands } \\
\text { Rural area (D) }\end{array}$ \\
\hline $\begin{array}{c}\text { Services for } \\
\text { the } \\
\text { Community } \\
\text { (SOCIAL) }\end{array}$ & $8(3 \%)$ & $\begin{array}{l}\text { FCIs aimed at } \\
\text { enhancing social } \\
\text { cohesion, creating a } \\
\text { sense of } \\
\text { community while } \\
\text { actively engaged in } \\
\text { forest management. } \\
\text { This includes } \\
\text { everything from } \\
\text { social forestry to } \\
\text { initiatives in which } \\
\text { the forest nurtures } \\
\text { spiritual values and } \\
\text { through the } \\
\text { creation of burial } \\
\text { forests or by } \\
\text { hosting spiritual } \\
\text { communities and } \\
\text { their deities. } \\
\text { Community food } \\
\text { forests also fall } \\
\text { under this category, } \\
\text { providing organic } \\
\text { food, opportunities } \\
\text { for learning about } \\
\text { sustainable } \\
\text { agricultural } \\
\text { practices, occasions } \\
\text { for social contact } \\
\text { and bonding, } \\
\text { enhancing the } \\
\text { sense of place, and } \\
\text { a refuge from } \\
\text { urban routine and } \\
\text { stress. }\end{array}$ & $\begin{array}{l}\text { Synergic } \\
\text { benefits }\end{array}$ & Social & $\begin{array}{c}\text { General } \\
\text { public } \\
\text { Self-leading }\end{array}$ & 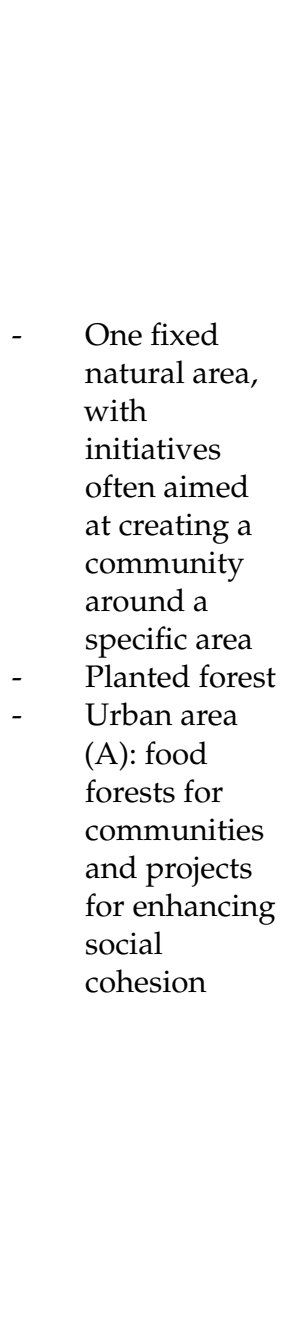 \\
\hline
\end{tabular}


Table 2. Cont.

\begin{tabular}{|c|c|c|c|c|c|c|}
\hline Typology & $\begin{array}{l}\text { N (\%) of Cases } \\
\text { Identified } \\
\text { within the } \\
\text { Repository }\end{array}$ & Description & Category & $\begin{array}{c}\text { Contributions } \\
\text { to Health and } \\
\text { Activities } \\
\text { Supported }\end{array}$ & Target Users & $\begin{array}{l}\text { Environment } \\
\text { Substitutability }\end{array}$ \\
\hline $\begin{array}{l}\text { Wilderness } \\
\text { and } \\
\text { Adventure } \\
\text { (WILD) }\end{array}$ & $5(2 \%)$ & $\begin{array}{l}\text { FCIs offering, } \\
\text { especially to } \\
\text { city-dwellers with } \\
\text { decreasing } \\
\text { occasions for deep } \\
\text { contact with nature, } \\
\text { the opportunity to } \\
\text { stay in the wild } \\
\text { while experiencing } \\
\text { a sense of } \\
\text { adventure. Such } \\
\text { initiatives offer } \\
\text { unique } \\
\text { opportunities to } \\
\text { interact with nature } \\
\text { in the wild and } \\
\text { learn new skills, } \\
\text { from survival to } \\
\text { fine motricity and } \\
\text { collaborative } \\
\text { problem-solving. }\end{array}$ & $\begin{array}{l}\text { Synergic } \\
\text { benefits }\end{array}$ & Social & $\begin{array}{l}\text { General } \\
\text { public } \\
\text { Assisted }\end{array}$ & $\begin{array}{ll}\text { - } & \text { Mainly one } \\
\text { fixed natural } \\
\text { area (also } \\
\text { itinerant) } \\
\text { - } \quad \text { Mainly } \\
\text { forests and } \\
\text { woodlands } \\
\text { - } \\
\text { Rural areas } \\
\text { (D) }\end{array}$ \\
\hline
\end{tabular}

\subsection{General Description and Location}

As seen in the results, information on the hosting environments and locations of FCIs was scarce. This seems to further confirm the limited focus on the environment when speaking of forests and health. FCIs belonging to the ART and EDU typologies were the oldest groups of initiatives, dating back to the late 1950s (except for Sacro Bosco di Bomarzo, founded in 1552), while the other FCIs were established around 2000. Geographical distribution followed the general trends described in Section 3.1, with the only exception being EDU initiatives, which were mainly located in Central Italy, in particular in Lazio $(17 \%)$. This can be attributed to the fact that one of the first Italian forest kindergartens was created in Lazio in 2012, and it is still very active in lobbying, advocating, and training, with the aim to support the development of outdoor schools and kindergartens.

EDU and SI initiatives were mainly located in urban areas, while the other FCI categories were mainly located in rural ones. This may be partially explained by considering that the EDU typology is mainly composed of forest schools and kindergartens that are active 4-5 days a week. Thus, it is legitimate to suppose that being close to the urban and peri-urban area might contribute to success and accessibility. For the SI typology, the main reason to be located in urban areas was the methodological choice we made to register the FCIs by their legal or operative headquarters when the initiative was reported as itinerant. On the other hand, the WELL typology alone comprised $50 \%$ of the total initiatives located in zone D rural areas, mainly in Trentino-Alto Adige since $48 \%$ of the WELL FCIs are located in this region.

\subsection{Contributions, Effects, and Activities and Practices Supported}

We observed a clear relationship between FCI typologies and the declared contribution to wellbeing. The FT typology has a predominance of physiological contributions, but nevertheless they are quite balanced with the other two contributions. Since FCIs included in the FT typology are partnering with the social and health care sectors, they are more likely to be the only typology able to pursue specific physiological contributions to health which require specific competencies and instruments to be assessed. The ART, EDU, SI, 
and SOCIAL typologies claim social contributions to wellbeing for almost all of their initiatives. These FCIs would aim at social contributions to health with different levels of specificity, also according to the needs of their target users. The WELL typology is the only category of FCIs with a clear predominance of claimed psychological contributions to health. We observed that, apart from FT initiatives that presented a mix of multiple contributions in almost all cases, just the WELL and SI typologies showed a predominance of one type of contribution closely associated with another. In more detail, the WELL FCIs claim psychological (in 83\% of the initiatives reviewed) together with physiological $(67 \%)$ contributions. SI FCIs, on the contrary, claim social contributions in all the initiatives reviewed, followed by $50 \%$ of reviewed initiatives in which psychological contributions are also claimed.

\subsection{Target Users and Experience in the Forest}

While most of FCIs are offered to the public at large or specific target groups, initiatives categorized under the FT rehabilitation and SI typologies are mainly (i.e., 94\% and 55\%, respectively) targeted at people with special needs. Consequently, they require specific activities, programs, and trained staff. Whereas $91 \%$ of the EDU initiatives have a specific target of users (i.e., children engaged in outdoor or environmental education), only the ART and SOCIAL FCIs propose initiatives for wellbeing that are mainly self-led by the users, meaning that the natural area is accessible and the benefits are enjoyable without the mediation of an expert or a guide.

\subsection{Hosting Natural Area}

Most of the FCIs analyzed were linked to a fixed natural area or areas. Indeed, both the WELL and WILD categories showed a predominance of initiatives bonded to a fixed natural area (48\% and 60\%, respectively) and itinerant initiatives (35\% and $40 \%$, respectively). Nevertheless, FT initiatives presented a fair division between the three modalities identified (i.e., one fixed area, more than one fixed area, and itinerant). This shows that within FCI categories, there can be a variability determined by the type of bond with the hosting natural ecosystem. Although most of the initiatives are based in forests and woodland areas, options reported for the EDU and SI typologies were prevalently mixed or not specified. The not specified option mainly refers to EDU initiatives, as information on the natural environment is often omitted. SI initiatives are mainly associated with the mixed entries, since they often involve woodlands and other ecosystems in mountainous areas. As for the type of forest, no deviations from the general trends observed for all FCIs could be observed with regard to individual FCI categories, due to the lack of detailed information with regard to most of the FCIs.

Forests and woodlands can effectively host both specific treatments and interventions with broader aims for wellbeing promotion. However, we observed different levels of substitutability of the forest ecosystem, with the wellbeing effects remaining the same. Substitutability can occur between (1) forests (or woodlands) and other ecosystems. For example, an FCI promoting barefoot walks, which can also be held in a non-forest context without losing its purpose and core values, but being in a forest would guarantee some benefits [6], and (2) different forests and even trails within the forest. For example, the forest therapy bases in Japan (For more details on forest therapy bases and examples, readers can refer to the website https:/ / www.fo-society.jp/therapy/cn45/index_en.html (accessed on 20 November 2020)) are strictly site-specific, depending on certified trails on the basis of ad hoc clinical studies assessing their effectiveness. In this case, changing the forest site can modify the type or intensity of any health effects, as well as the objectives of the intervention. Yet, there can be substantial differences within the same class of initiatives that can be captured through substitutability. For example, some WELL FCIs are more linked to a fixed natural space, likely (1) for logistic or practical reasons (e.g., ownership or proximity), and (2) for the role of specific environmental features (e.g., the emission of terpenes and monoterpenes or aesthetic value). On the contrary, itinerant 
WELL FCIs require a guide to allow participants to enjoy the experience in the forest, while less importance is given to the specificity of the forest elements. These aspects might enrich the perspectives of recent works that tried to identify and inventory natural spaces, enabling the provision of sociobehavioral and CES benefits using satellite imagery, spatial measurement tools, and participatory instruments (e.g., Google or Flickr.com) [49,86,87]. A deeper understanding of the natural spaces and their substitutability can increase the impact of FCIs and provide information for planning and management [86].

\subsection{FCIs Categorization Scheme}

We observed differences among FCI typologies both in terms of users and in the specificity of the care provided, from treatment sessions structured on users' needs with assisted interventions (e.g., forest-based therapy for people with disabilities) and self-help interventions (e.g., social prescribing for people at risk of cardiovascular diseases) to other interventions aimed at a broader promotion of wellbeing and healthy behaviors (e.g., forest bathing trails open for visitors).

It seems that the more specific the health benefits the initiative aims to achieve are, the more specific the targeted users are, while the substitutability of the forest ecosystem or even specific trails apparently decreases. According to this, we propose an inclusive and operational form of categorization, taking inspiration from and adapting previous works and literature from nature-based solutions [2,29,36,88]. Three categories (plus one) of FCIs are drafted with descriptions provided in Table 3. These categories are identified depending on how they move along three gradients (substitutability of the forest ecosystem, target users, and specificity of the health objectives), as illustrated in Figure 3.

Table 3. Description of the three categories of FCIs identified.

\section{Categories}

Treatment and Rehabilitation

Prevention and Promotion of Health and Wellbeing

\section{Descriptions}

Initiatives created in close collaboration with the health sector and professionals, where specific characteristics of the forest environment are used to develop ad hoc treatments, rehabilitation, and integrative therapies tailored for specific health conditions (both physical and psychological). Though not exclusively, they tend to address small groups of people with homogenous needs and are often proposed as a program rather than one-off visits. Objectives, activities, and the use of the forest environment tend to be tuned to target users 'needs.

Initiatives using the forest environment, taking advantage of the positive effects of forest exposure via specific activities and approaches for health promotion and preventive purposes (i.e., primary, secondary, and tertiary prevention). Such services are delivered to a large population, both with one-off and recurrent visits. The involvement of the health sector is not strictly necessary, as clinical services and the assistance of professional doctors are not needed.

Initiatives not aimed at providing specific health outcomes, but rather at enriching the social dimension of wellbeing while providing indirect or collateral health benefits through contact with the forest ecosystem. They enable the creation of synergies between the forest, health, and other sectors, supporting cross-sector collaborations across the education, tourism, recreation, and art and culture sectors. 


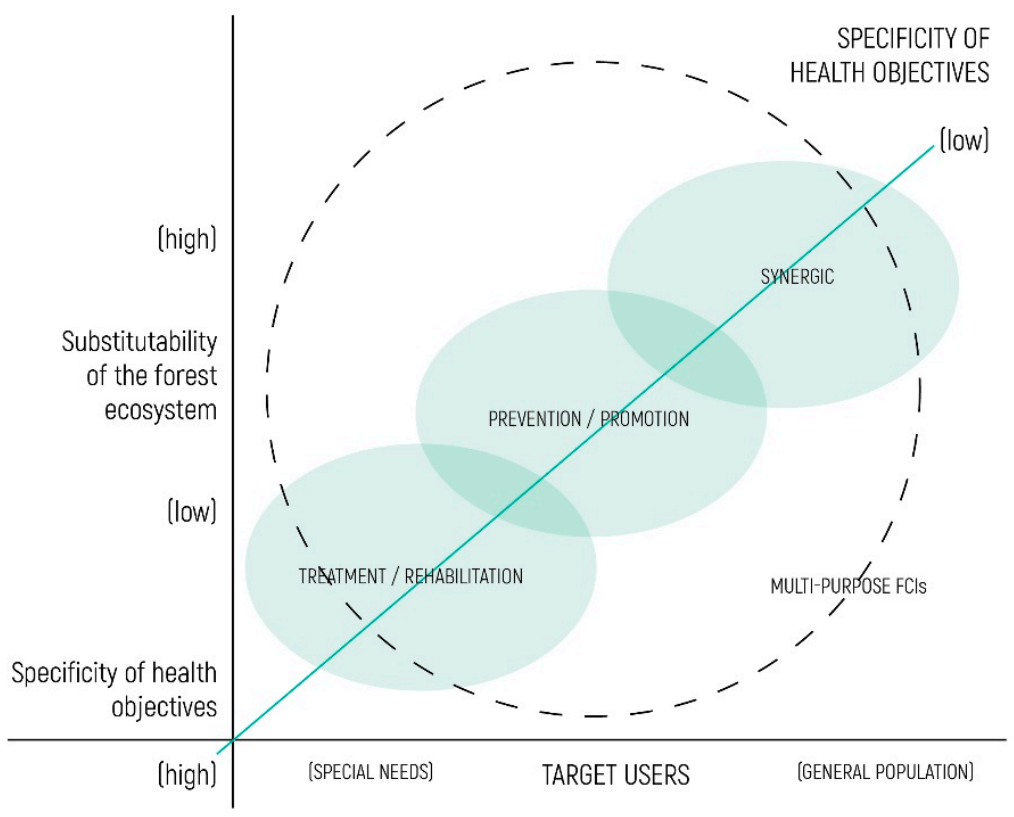

Figure 3. Categorization scheme of FCIs along three gradients.

The analysis and interpretation of real case-based FCIs typologies allowed us to see how single categories were flexible and single FCIs had degrees of freedom of movement across the gradients. An analysis at the FCI level would enable one to further explore the differences and new nuances of the proposed scheme.

\subsection{Strength and Limits}

By adopting an inductive process, this study started from the identification and analysis of activities and practices supported by forest ecosystems to highlight a representative set of activities and interactions and, finally, develop a possible framework for the main typologies of FCIs.

Besides contributing to shedding light on FCIs in general, the study investigated in detail the Italian context, emphasizing its specificities. Including just a narrow range of values (e.g., recreation and tourism) in planning and decision-making may cause conflicts between different stakes, missed opportunities for managers and policymakers, the increased possibility for policy failures, and ultimately, a reduction in human wellbeing [76]. The ART category emerged as specific to the Italian context, as it was not reported in other FCI reviews. Nevertheless, even if a characterization of FCIs by core activity is operational and easily understandable, almost all FCIs are characterized by multiple services, activities, and purposes. Both the definition and the categorization presented here are purposely flexible because, by considering the multifunctionality and the holistic approach that often characterize FCIs [36,89], a clear-cut definition and clustering is not possible and even not desirable.

Among the limitations of the study, the absence of a shared language or terminology, definitions, and databases were key, and this challenged the aim of the repository to reach a realistic representation of the number and typologies of FCIs in Italy. The interpretation of new concepts, which are often used with different meanings among the involved sectors, is also a challenge. Relying on disclosed information available online on the one side enhances the readiness of data collection, but on the other, it exposes studies to the risk of inaccuracy and data shortages. In fact, FCIs involving small groups of people with special needs are rarely made public through the media, presumably because they do not need to enlarge their customer base. SI initiatives are likely underrepresented in our study because of this. FCIs related to education and forest schools are mainly advertised through social media, like Facebook, with very basic information about the services offered and, in particular, the features and roles of forest ecosystems. Arguably, this is due to the fact that 
these initiatives are developed and managed by people outside the forest sector and with no specific forestry background.

Finally, limited information on the natural areas often made it impossible to precisely locate the FCIs. For standardization and readiness, we decided to lose some information and register one location per FCI (even when they were itinerant), as well as the operational headquarters when the location of the natural area was not clear.

\section{Conclusions}

This paper proposes an umbrella FCI term to develop a categorization framework for all initiatives using contact with the forest and woodland ecosystem as a means to increase the level of health and wellbeing of people and communities. Through extensive data collection and review, we inventoried FCIs in Italy. This allowed deepening of the knowledge about FCIs, identifying the typologies of initiatives that are sprouting and characterizing them for their differences and commonalities. These initiatives represent an element of novelty in respect to the traditional recreational and tourism activities linked to the forest sector. Here, the novelty is intended as an original combination of target users (i.e., specific targets and people with special needs), activities proposed (i.e., new services or new services for the sector), partnerships and stakeholders involved (i.e., collaboration with the health and social sectors), and the use of the forest environment (e.g., to treat specific diseases, provoke behavioral changes, inspire, or help relax). This analysis reveals that, in the last few decades, there was growth and spreading of FCIs in Italy, showing the great vitality of the private nonprofit sector. The analysis confirmed that a great wealth of wellbeing services has been delivered by forests in rural and marginal areas, as well as in urban and peri-urban areas, providing people with inclusive wellbeing services, opportunities for new green jobs, and business. In the effort to enhance bioeconomy, the emerging FCIs might indeed represent an opportunity for valuing forest multifunctionality and creating new spaces for sustainable economic and rural development through collaboration across different sectors. Nevertheless, in order to exploit these opportunities, knowledge about the initiatives and the role of the forest ecosystem in delivering wellbeing benefits shall be improved.

The proposed interpretation of categories and gradients advances the consideration of the environment as a pawn of the game, pushing for more research not just on the specific features (and their changes) responsible for wellbeing, but also on different green spaces that may allow the provision of such services. Enriching the knowledge about the dynamics through which FCIs can move along the three gradients can allow support for the role of both rural and urban forests as strategic assets for wellbeing. This also seems to gain increasing relevance in light of the recent need to have accessible and healthy natural areas to both prevent and cope with the spread of pandemics such as COVID-19 [90].

Supplementary Materials: The following are available online at https:/ / www.mdpi.com/2071-105 0/13/2/492/s1, Table S1: Complete Repository of Italian FCIs Analyzed.

Author Contributions: Database searching, application of inclusion criteria, analyses, and original draft preparation, I.D.; study design and methodology definition, I.D., M.M., and P.G.; review and editing, M.M.; supervision, P.G. All authors have read and agreed to the published version of the manuscript.

Funding: This work is part of a Ph.D. research project developed within the Land, Environment, Health and Resource PhD Program at the Department of Land, Environment, Agriculture and Forestry, Università degli Studi di Padova, and co-founded by Etifor srl. Etifor did not have any specific involvement in the development of this research.

Data Availability Statement: Data presented in this study are contained within the Supplementary Material, for any other request contact the corresponding author.

Conflicts of Interest: The authors declare no conflict of interest. 


\section{References}

1. European Commission. Committee and the Committee of the Regions EU Biodiversity Strategy for 2030 Bringing Nature Back into our Lives. 2020. Available online: https://eur-lex.europa.eu/legal-content/EN/TXT/?uri=CELEX:52020DC0380 (accessed on 4 January 2021).

2. Haluza, D.; Schönbauer, R.; Cervinka, R. Green perspectives for public health: A narrative review on the physiological effects of experiencing outdoor nature. Int. J. Environ. Res. Public Health 2014, 11, 5445-5461. [CrossRef] [PubMed]

3. Hartig, T.; Mitchell, R.; de Vries, S.; Frumkin, H. Nature and Health. Annu. Rev. Public Health 2014. [CrossRef] [PubMed]

4. Van den Bosch, M. Ode Sang Urban natural environments as nature-based solutions for improved public health-A systematic review of reviews. Environ. Res. 2017, 158, 373-384. [CrossRef] [PubMed]

5. Hansen, M.M.; Jones, R.; Tocchini, K. Shinrin-yoku (Forest bathing) and nature therapy: A state-of-the-art review. Int. J. Environ. Res. Public Health 2017, 14, 851. [CrossRef] [PubMed]

6. Doimo, I.; Masiero, M.; Gatto, P. Forest and Wellbeing: Bridging Medical and Forest Research for Effective Forest-Based Initiatives. Forests 2020, 11, 791. [CrossRef]

7. Jeon, J.Y.; Yeon, P.S.; Shin, W.S. The influence of indirect nature experience on human system. For. Sci. Technol. 2018, 14, 29-32. [CrossRef]

8. Song, C.; Ikei, H.; Miyazaki, Y. Elucidation of the physiological adjustment effect of forest therapy. Nihon Eiseigaku Zasshi. 2014, 69, 111-116. [CrossRef]

9. Kim, J.-C.; Dinh, T.-V.; Oh, H.-K.; Son, Y.-S.; Ahn, J.-W.; Song, K.-Y.; Choi, I.-Y.; Park, C.-R.; Suzlejko, J.; Kim, K.-H. The Potential Benefits of Therapeutic Treatment Using Gaseous Terpenes at Ambient Low Levels. Appl. Sci. 2019, 9, 4507. [CrossRef]

10. Ikei, H.; Song, C.; Kagawa, T.; Miyazaki, Y. Physiological and psychological effects of viewing forest landscapes in a seated position in one-day forest therapy experimental model. Nihon Eiseigaku Zasshi. 2014, 69, 104-110. [CrossRef]

11. Song, C.; Ikei, H.; Miyazaki, Y. Physiological effects of forest-related visual, olfactory, and combined stimuli on humans: An additive combined effect. Urban For. Urban Green. 2019, 44, 126437. [CrossRef]

12. Song, C.; Ikei, H.; Miyazaki, Y. Physiological effects of visual stimulation with forest imagery. Int. J. Environ. Res. Public Health 2018, 15, 213. [CrossRef] [PubMed]

13. Bielinis, E.; Jaroszewska, A.; Łukowski, A.; Takayama, N. The effects of a forest therapy programme on mental hospital patients with affective and psychotic disorders. Int. J. Environ. Res. Public Health 2019, 17, 118. [CrossRef] [PubMed]

14. Farrow, M.R.; Washburn, K. A Review of Field Experiments on the Effect of Forest Bathing on Anxiety and Heart Rate Variability. Glob. Adv. Heal. Med. 2019, 8, 216495611984865. [CrossRef] [PubMed]

15. Guan, H.; Wei, H.; He, X.; Ren, Z.; An, B. The tree-species-specific effect of forest bathing on perceived anxiety alleviation of young-adults in urban forests. Ann. For. Res. 2017, 60, 327-341. [CrossRef]

16. Shin, W.S.; Yeoun, P.S.; Yoo, R.W.; Shin, C.S. Forest experience and psychological health benefits: The state of the art and future prospect in Korea. Environ. Health Prev. Med. 2010, 15, 38-47. [CrossRef]

17. Takayama, N.; Korpela, K.; Lee, J.; Morikawa, T.; Tsunetsugu, Y.; Park, B.J.; Li, Q.; Tyrväinen, L.; Miyazaki, Y.; Kagawa, T. Emotional, restorative and vitalizing effects of forest and urban environments at four sites in Japan. Int. J. Environ. Res. Public Health 2014, 11, 7207-7230. [CrossRef]

18. Chun, M.H.; Chang, M.C.; Lee, S.-J. The effects of forest therapy on depression and anxiety in patients with chronic stroke. Int. J. Neurosci. 2017, 127, 199-203. [CrossRef]

19. Ohe, Y.; Ikei, H.; Song, C.; Miyazaki, Y. Evaluating the relaxation effects of emerging forest-therapy tourism: A multidisciplinary approach. Tour. Manag. 2017, 62, 322-334. [CrossRef]

20. Joung, D.; Kim, G.; Choi, Y.; Lim, H.; Park, S.; Woo, J.-M.; Park, B.-J. The prefrontal cortex activity and psychological effects of viewing forest landscapes in Autumn season. Int. J. Environ. Res. Public Health 2015, 12, 7235-7243. [CrossRef]

21. Park, B.J.; Tsunetsugu, Y.; Kasetani, T.; Kagawa, T.; Miyazaki, Y. The physiological effects of Shinrin-yoku (taking in the forest atmosphere or forest bathing): Evidence from field experiments in 24 forests across Japan. Environ. Health Prev. Med. 2010, 15, 18-26. [CrossRef]

22. Song, C.; Joung, D.; Ikei, H.; Igarashi, M.; Aga, M.; Park, B.J.; Miwa, M.; Takagaki, M.; Miyazaki, Y. Physiological and psychological effects of walking on young males in urban parks in winter. J. Physiol. Anthropol. 2013, 32, 18. [CrossRef] [PubMed]

23. Cooper, N.; Brady, E.; Steen, H.; Bryce, R. Aesthetic and spiritual values of ecosystems: Recognising the ontological and axiological plurality of cultural ecosystem "services". Ecosyst. Serv. 2017, 21, 218-229. [CrossRef]

24. Dadvand, P.; Hariri, S.; Abbasi, B.; Heshmat, R.; Qorbani, M.; Motlagh, M.E.; Basagaña, X.; Kelishadi, R. Use of green spaces, self-satisfaction and social contacts in adolescents: A population-based CASPIAN-V study. Environ. Res. 2019, 168, 171-177. [CrossRef] [PubMed]

25. O'Brien, L.; Morris, J.; Stewart, A. Engaging with peri-urban woodlands in England: The contribution to people's health and well-being and implications for future management. Int. J. Environ. Res. Public Health 2014, 11, 6171-6192. [CrossRef]

26. O'Brien, E. Social and Cultural Values of Trees and Woodlands in Northwest and Southeast England. For. Snow Landsc. Res. 2005, 79, 169-184.

27. Kuo, M.; Barnes, M.; Jordan, C. Do experiences with nature promote learning? Converging evidence of a cause-and-effect relationship. Front. Psychol. 2019, 10, 305. [CrossRef] 
28. James, S.L.; Abate, D.; Abate, K.H.; Abay, S.M.; Abbafati, C.; Abbasi, N.; Abbastabar, H.; Abd-Allah, F.; Abdela, J.; Abdelalim, A.; et al. Global, regional, and national incidence, prevalence, and years lived with disability for 354 Diseases and Injuries for 195 countries and territories, 1990-2017: A systematic analysis for the Global Burden of Disease Study 2017. Lancet 2018, 392, 1789-1858. [CrossRef]

29. Cervinka, R.; Höltge, J.; Pirgie, L.; Schwab, M.; Sudkamp, J.; Haluza, D.; Arnberger, A.; Eder, R.; Ebenberger, M.; Lackner, C.; et al. Green Public Health-Benefits of Woodlands on Human Health and Well-Being; Bundesforschungszentrum für Wald (BFW): Vienna, Austria, 2014.

30. Hine, R.; Peacock, J.; Pretty, J. Care Farming in the UK: Evidence and Opportunities Care Farming in the UK-Evidence and Opportunities Report for the National Care Farming Initiative (UK). Report for National Care Farming Institute (UK). 2008. Available online: https: / / www.semanticscholar.org/paper/Care-farming-in-the-UK\%3A-Evidence-and-Opportunities-HinePeacock/9de122ad711dbddfa2c6201b8de00393d3f5040c (accessed on 4 January 2021).

31. Andkjær, S.; Arvidsen, J. Places for active outdoor recreation-a scoping review. J. Outdoor Recreat. Tour. 2015, 12, 25-46. [CrossRef]

32. Lawrence, G.A. The "Wellness" Phenomenon: Implications for Global Agri-Food Systems. In Food Security, Nutrition and Sustainability; Earthscan: London, UK; Sterling, VA, USA, 2010; pp. 175-187. [CrossRef]

33. Dessein, J.; Bock, B.B.; De Krom, M.P.M.M. Investigating the limits of multifunctional agriculture as the dominant frame for Green Care in agriculture in Flanders and the Netherlands. J. Rural. Stud. 2013, 32, 50-59. [CrossRef]

34. Woods, M. Rural Geography: Processes, Responses and Experiences in Rural Restructuring-Michael Woods—Google Libri; SAGE: London, UK, 2004. [CrossRef]

35. Cubbage, F.; Harou, P.; Sills, E. Policy instruments to enhance multi-functional forest management. For. Policy Econ. 2007, 9, 833-851. [CrossRef]

36. Marušáková, L'.; Sallmannshofer, M. Human Health and Sustainable Forest Management; Marusakova, L., Sallmannshofer, M., Eds.; FOREST EUROPE—Liaison Unit Bratislava: Zvolen, Slovakia, 2019; ISBN 978-80-8093-266-4.

37. Hassink, J.; van Dijk, M. Farming for Health across Europe: Comparison between countries, and recommendations for a research and policy agenda. In Farming for Health; Springer: Dordrecht, The Netherlands, 2006; pp. 345-357.

38. Di Iacovo, F.; O'Connor, D. Supporting policies for Social Farming in Europe Progressing Multifunctionality in Responsive Rural Areas; ARSIA: Firenze, Italy, 2009; ISBN 978-88-8295-107-8.

39. Haubenhofer, D.K.; Elings, M.; Hassink, J.; Hine, R.E.; Menv, B. The development of green care in western european countries. Explore 2010, 6, 106-111. [CrossRef] [PubMed]

40. Rosa, C.D.; Collado, S. Experiences in nature and environmental attitudes and behaviors: Setting the ground for future research Front. Psychol. 2019, 10, 763. [CrossRef]

41. Akpinar, A. How is high school greenness related to students' restoration and health? Urban For. Urban Green. 2016, 16, 1-8. [CrossRef]

42. Jay, M.; Schraml, U. Understanding the role of urban forests for migrants—uses, perception and integrative potential. Urban For. Urban Green. 2009, 8, 283-294. [CrossRef]

43. Waite, S.; Goodenough, A. What is different about Forest School? Creating a space for an alternative pedagogy in England. J. Outdoor Environ. Educ. 2018, 21, 25-44. [CrossRef]

44. Coscieme, L. Cultural ecosystem services: The inspirational value of ecosystems in popular music. Ecosyst. Serv. 2015, 16, 121-124. [CrossRef]

45. Clayden, A.; Green, T.; Hockey, J.; Powell, M. Cutting the lawn-Natural burial and its contribution to the delivery of ecosystem services in urban cemeteries. Urban For. Urban Green. 2018, 33, 99-106. [CrossRef]

46. Chan, K.M.A.; Guerry, A.D.; Balvanera, P.; Klain, S.; Satterfield, T.; Basurto, X.; Bostrom, A.; Chuenpagdee, R.; Gould, R.; Halpern, B.S.; et al. Where are Cultural and Social in Ecosystem Services? A Framework for Constructive Engagement. Bioscience 2012, 62, 744-756. [CrossRef]

47. Hirons, M.; Comberti, C.; Dunford, R. Valuing Cultural Ecosystem Services. Annu. Rev. Environ. Resour. 2016, 41, 545-574. [CrossRef]

48. McDonough, K.; Hutchinson, S.; Moore, T.; Hutchinson, J.M.S. Analysis of publication trends in ecosystem services research. Ecosyst. Serv. 2017, 25, 82-88. [CrossRef]

49. Bach Pagès, A.; Peñuelas, J.; Clarà, J.; Llusià, J.; Campillo i López, F.; Maneja, R. How Should Forests Be Characterized in Regard to Human Health? Evidence from Existing Literature. Int. J. Environ. Res. Public Health 2020, 17, 1027. [CrossRef] [PubMed]

50. Morita, E.; Imai, M.; Okawa, M.; Miyaura, T.; Miyazaki, S. A before and after comparison of the effects of forest walking on the sleep of a community-based sample of people with sleep complaints. Biopsychosoc. Med. 2011, 5, 13. [CrossRef] [PubMed]

51. López-Pousa, S.; Bassets Pagès, G.; Monserrat-Vila, S.; de Gracia Blanco, M.; Hidalgo Colomé, J.; Garre-Olmo, J. Sense of Well-Being in Patients with Fibromyalgia: Aerobic Exercise Program in a Mature Forest-A Pilot Study. Evid. Based. Complement. Alternat. Med. 2015, 2015, 614783. [CrossRef] [PubMed]

52. Lee, I.; Choi, H.; Bang, K.-S.; Kim, S.; Song, M.K.; Lee, B. Effects of forest therapy on depressive symptoms among adults: A systematic review. Int. J. Environ. Res. Public Health 2017, 14, 321. [CrossRef]

53. Shin, W.S.; Shin, C.S.; Yeoun, P.S. The influence of forest therapy camp on depression in alcoholics. Environ. Health Prev. Med. 2012, 17, 73-76. [CrossRef] 
54. Han, J.-W.; Choi, H.; Jeon, Y.-H.; Yoon, C.-H.; Woo, J.-M.; Kim, W. The effects of forest therapy on coping with chronic widespread pain: Physiological and psychological differences between participants in a forest therapy program and a control group. Int. J. Environ. Res. Public Health 2016, 13, 255. [CrossRef]

55. Mao, G.; Cao, Y.; Wang, B.; Wang, S.; Chen, Z.; Wang, J.; Xing, W.; Ren, X.; Lv, X.; Dong, J.; et al. The salutary influence of forest bathing on elderly patients with chronic heart failure. Int. J. Environ. Res. Public Health 2017, 14, 368. [CrossRef]

56. Kim, B.J.; Jeong, H.; Park, S.; Lee, S. Forest adjuvant anti-cancer therapy to enhance natural cytotoxicity in urban women with breast cancer: A preliminary prospective interventional study. Eur. J. Integr. Med. 2015, 7, 474-478. [CrossRef]

57. Li, Q.; Morimoto, K.; Kobayashi, M.; Inagaki, H.; Katsumata, M.; Hirata, Y.; Hirata, K.; Shimizu, T.; Li, Y.J.; Wakayama, Y.; et al. A forest bathing trip increases human natural killer activity and expression of anti-cancer proteins in female subjects. J. Biol. Regul. Homeost. Agents 2008, 22, 45-55.

58. Li, Q.; Morimoto, K.; Nakadai, A.; Inagaki, H.; Katsumata, M.; Shimizu, T.; Hirata, Y.; Hirata, K.; Suzuki, H.; Miyazaki, Y.; et al. Forest bathing enhances human natural killer activity and expression of anti-cancer proteins. Int. J. Immunopathol. Pharmacol. 2007, 20, 3-8. [CrossRef]

59. Li, Q.; Nakadai, A.; Matsushima, H.; Miyazaki, Y.; Krensky, A.; Kawada, T.; Morimoto, K. Phytoncides (wood essential oils) induce human natural killer cell activity. Immunopharmacol. Immunotoxicol. 2006, 28, 319-333. [CrossRef] [PubMed]

60. Morris, J.; O’Brien, E. Encouraging healthy outdoor activity amongst under-represented groups: An evaluation of the Active England woodland projects. Urban For. Urban Green. 2011, 10, 323-333. [CrossRef]

61. Bang, K.S.; Kim, S.; Song, M.K.; Kang, K.I.; Jeong, Y. The effects of a health promotion program using urban forests and nursing student mentors on the perceived and psychological health of elementary school children in vulnerable populations. Int. J. Environ. Res. Public Health 2018, 15, 1977. [CrossRef] [PubMed]

62. Richardson, M.; Cormack, A.; McRobert, L.; Underhill, R. 30 days wild: Development and evaluation of a large-scale nature engagement campaign to improve well-being. PLoS ONE 2016, 11, e0149777. [CrossRef] [PubMed]

63. Takayama, N.; Morikawa, T.; Bielinis, E. Relation between psychological restorativeness and lifestyle, quality of life, resilience, and stress-coping in forest settings. Int. J. Environ. Res. Public Health 2019, 16, 1456. [CrossRef]

64. Westlund, S. Becoming human again': Exploring connections between nature and recovery from stress and post-traumatic distress. Work 2015, 50, 161-174. [CrossRef]

65. Poulsen, D.V.; Stigsdotter, U.K.; Djernis, D.; Sidenius, U. 'Everything just seems much more right in nature': How veterans with post-traumatic stress disorder experience nature-based activities in a forest therapy garden. Health Psychol. Open 2016, 3. [CrossRef]

66. Bachinger, M.; Rau, H. Forest-Based Health Tourism as a Tool for Promoting Sustainability; Springer: Cham, Switzerland, 2019; pp. 87-104.

67. Sung, J.; Woo, J.-M.; Kim, W.; Lim, S.-K.; Chung, E.-J. The effect of cognitive behavior therapy-based "forest therapy" program on blood pressure, salivary cortisol level, and quality of life in elderly hypertensive patients. Clin. Exp. Hypertens. 2012, 34, 1-7. [CrossRef]

68. Oh, K.H.; Shin, W.S.; Khil, T.G.; Kim, D.J. Six-step model of nature-based therapy process. Int. J. Environ. Res. Public Health 2020, 17, 685. [CrossRef]

69. Vujcic, M.; Tomicevic-Dubljevic, J.; Grbic, M.; Lecic-Tosevski, D.; Vukovic, O.; Toskovic, O. Nature based solution for improving mental health and well-being in urban areas. Environ. Res. 2017, 158, 385-392. [CrossRef]

70. Maller, C.; Townsend, M.; Pryor, A.; Brown, P.; St Leger, L. Healthy nature healthy people: "contact with nature" as an upstream health promotion intervention for populations. Health Promot. Int. 2006, 21, 45-54. [CrossRef] [PubMed]

71. Forest Therapy Society. Available online: https://www.fo-society.jp/en/index.html (accessed on 16 October 2020).

72. Kondo, M.C.; Oyekanmi, K.O.; Gibson, A.; South, E.C.; Bocarro, J.; HipNp, J.A. Mature prescriptions for health: A review of evidence and research opportunities. Int. J. Environ. Res. Public Health 2020, 17, 4213. [CrossRef] [PubMed]

73. Leavell, M.A.; Leiferman, J.A.; Gascon, M.; Braddick, F.; Gonzalez, J.C.; Litt, J.S. Nature-Based Social Prescribing in Urban Settings to Improve Social Connectedness and Mental Well-being: A Review. Curr. Environ. Health Reports 2019, 6, 297-308. [CrossRef] [PubMed]

74. Karjalainen, E.; Sarjala, T.; Raitio, H. Promoting human health through forests: Overview and major challenges. Environ. Health Prev. Med. 2009, 15, 1-8. [CrossRef] [PubMed]

75. Sattler, C.; Matzdorf, B. PES in a nutshell: From definitions and origins to PES in practice-Approaches, design process and innovative aspects. Ecosyst. Serv. 2013, 6, 2-11. [CrossRef]

76. Fish, R.; Church, A.; Willis, C.; Winter, M.; Tratalos, J.A.; Haines-Young, R.; Potschin, M. Making space for cultural ecosystem services: Insights from a study of the UK nature improvement initiative. Ecosyst. Serv. 2016, 21, 329-343. [CrossRef]

77. Rawcliffe, P. Cultural Ecosystem Services-Towards a Common Framework for Developing Policy and Practice in Scotland Available online: https:/ / www.nature.scot/sites/default/files/2017-06/Cultural\%20ecosystem\%20Services\%20-\%20towards\% 20a\%20common\%20framework\%20for\%20developing\%20policy\%20and\%20practice \%20in \%20Scotland \%20-\%20Working \%20 Paper\%20-\%20October\%202015\%20-\%20final\%20for\%20web\%20(February\%202016).pdf (accessed on 4 January 2021).

78. FAO. The Global Forest Resources Assessment 2015 Terms and Definitions; FAO: Rome, Italy, 2015. 
79. Coleman, K.J.; Perry, E.E.; Thom, D.; Gladkikh, T.M.; Keeton, W.S.; Clark, P.W.; Tursini, R.E.; Wallin, K.F. The woods around the ivory tower: A systematic review examining the value and relevance of school forests in the United States. Sustainability 2020, 12, 531. [CrossRef]

80. Glaser, B.B.; Strauss, A.L. The discovery of Grounded theory. Strategies for Qualitative Research; AldineTransaction: Piscataway, NJ, USA, 1967; Volume 66-28314, ISBN 0-202-30260-1.

81. Rete Rurale Nazionale. Rapporto Annuale sul Settore Forestale; Compagnia delle Foreste: Arezzo, Italy, 2019 ; ISBN 9788898850341.

82. INFC Secondo Inventario Nazionale (INFC2005). Available online: https:/ /www.sian.it/inventarioforestale/jsp/dati_introa.jsp? menu=3 (accessed on 5 November 2020).

83. Secco, L.; Pettenella, D.; Gatto, P. Forestry governance and collective learning process in Italy: Likelihood or utopia? For. Policy Econ. 2011, 13, 104-112. [CrossRef]

84. Secco, L.; Paletto, A.; Romano, R.; Masiero, M.; Pettenella, D.; Carbone, F.; De Meo, I. Orchestrating forest policy in Italy: Mission impossible? Forests 2018, 9, 468. [CrossRef]

85. UNECE, United Nations. Green Jobs in the Forest Sector. Available online: https://unece.org/DAM/timber/publications/DP7 1_WEB.pdf (accessed on 4 January 2021).

86. Barnes, M.R.; Donahue, M.L.; Keeler, B.L.; Shorb, C.M.; Mohtadi, T.Z.; Shelby, L.J. Characterizing Nature and Participant Experience in Studies of Nature Exposure for Positive Mental Health: An Integrative Review. Front. Psychol. $2019,9,2617$. [CrossRef]

87. Frascaroli, F.; Zannini, P.; Teresa, A.; Acosta, R.; Chiarucci, A.; Nascimbene, J. Sacred natural sites in Italy have landscape characteristics complementary to protected areas: Implications for policy and planning. Appl. Geogr. 2019, 113, 102100. [CrossRef]

88. Eggermont, H.; Balian, E.; Azevedo, M.N.; Beumer, V.; Brodin, T.; Claudet, J.; Fady, B.; Grube, M.; Keune, H.; Lamarque, P.; et al. Nature-based Solutions: New Influence for Environmental Management and Research in Europe Nature-based Solutions: New Influence for Environmental Management and Research in Europe I GAIA 24/4 (2015): 243-248 Nature-based Solutions, an Emerging Term. Ecol. Perspect. Sci. Soc. 2015, 24, 243-248. [CrossRef]

89. Plieninger, T.; Bieling, C.; Fagerholm, N.; Byg, A.; Hartel, T.; Hurley, P.; Sar, C.; Ló Pez-Santiago, A.; Nagabhatla, N.; OterosRozas, E.; et al. The role of cultural ecosystem services in landscape management and planning. Curr. Opin. Environ. Sustain. 2015, 14, 28-33. [CrossRef]

90. Naomi, A.S. Access to Nature Has Always Been Important; With COVID-19, It Is Essential. Heal. Environ. Res. Des. J. 2020, 13, 242-244. 